Financial Management 


\section{ESSENTIALS OF NURSING MANAGEMENT}

Other titles in the series

Annabel Broome: Managing Change, 2nd edition

Principles of complex change

Leadership and creating change from within

Imposed to change

The nurse as a change agent

Identifying training and development needs

Appendices

June Girvin: Leadership and Nursing

The development of theories of leadership

Interpretations of leadership

Interpersonal skills and leadership

Leadership in nursing

The story so far...

Traditional attitudes and socialisation

Motivation

Leadership today

Vision - foresight, insight and dreams

Diana Sale: Quality Assurance, 2nd edition

An introduction to quality assurance

Total quality management

Standards of care

Clinical audit

Clinical protocols

Monitoring of providers by purchasers

Verena Tschudin with Jane Schober: Managing Yourself, 2nd edition

'Know thyself'

Valuing yourself

Motivating yourself

Asserting yourself

Stressing yourself

Supporting yourself

Celebrating yourself

Developing yourself and your career 
ESSENTIALS OF NURSING MANAGEMENT

\section{Financial Management}

Geoffrey Woodhall

and

Alan Stuttard 


\section{}

(C) Geoffrey Woodhall and Alan Stuttard 1999

All rights reserved. No reproduction, copy or transmission of this publication may be made without written permission.

No paragraph of this publication may be reproduced, copied or transmitted save with written permission or in accordance with the provisions of the Copyright, Designs and Patents Act 1988 , or under the terms of any licence permitting limited copying issued by the Copyright Licensing Agency, 90 Tottenham Court Road, London W1P OLP.

Any person who does any unauthorised act in relation to this publication may be liable to criminal prosecution and civil claims for damages.

The authors have asserted their right to be identified as the authors of this work in accordance with the Copyright, Designs and Patents Act 1988.

First published 1999 by

MACMILLAN PRESS LTD

Houndmills, Basingstoke, Hampshire RG21 6XS

and London

Companies and representatives

throughout the world

ISBN 978-0-333-59369-1

ISBN 978-1-349-13199-0 (eBook)

DOI 10.1007/978-1-349-13199-0

A catalogue record for this book is available from the British Library.

This book is printed on paper suitable for recycling and made from fully managed and sustained forest sources.

$\begin{array}{cccccccccc}10 & 9 & 8 & 7 & 6 & 5 & 4 & 3 & 2 & 1 \\ 08 & 07 & 06 & 05 & 04 & 03 & 02 & 01 & 00 & 99\end{array}$

Editing and origination by Aardvark Editorial, Mendham, Suffolk 


\section{Dedicated to}

Joan Corcoran, Manager, Occupational Therapy Services, Royal Preston Hospital

Eileen Jones, Business Manager, Directorate of Obstetrics and Gynaecology, Queen's Medical Centre, Nottingham

$$
\text { and }
$$

Ada Thompson, Head of Community Nursing, Lancaster whose enthusiasm and professionalism inspired this book 


\section{Contents}

List of Figures and Tables

ix

Introduction

1

Chapter 1 An Introduction to Finance in the Health

Service: The Role of Central Government 3

Structure of the NHS 3

Financial Planning at a National Level 5

Financial Planning at a Local Level 8

NHS Trusts 9

Types of Contract $\quad 10$

Further Reading $\quad 12$

Chapter 2 The Planning and Control of Capital

Expenditure: Preparing Capital Estimates 14

Introduction 14

Current Expenditure $\quad 14$

Planning for Capital 15

Contract Terms 15

Costing a Capital Scheme $\quad 17$

Interim and Final Certificates for Payments to Contractors $\quad 20$

Efficiency Savings $\quad 23$

Self-study Questions $\quad 25$

Further Reading 25

Chapter 3 Methods of Capital Appraisal 26

Introduction $\quad 26$

Capital Appraisal $\quad 27$ 


\section{Contents}

Self-study Questions $\quad 35$

Further Reading $\quad 36$

Chapter 4 Sources of Capital Finance - Paying for Capital

Expenditure Schemes and Capital Allocation 37

Introduction 37

Sources of Funds $\quad 37$

Leasing/Facilities Management 39

Further Reading $\quad 40$

Chapter 5 The Planning and Control of Revenue

Expenditure $\quad 41$

Self-study Questions $\quad 50$

Further Reading $\quad 50$

Chapter 6 Setting a Budget for the First Time 51

Introduction 51

Types of Cost 51

Self-study Questions $\quad 56$

Further Reading $\quad 56$

Chapter 7 Monitoring of Budget Performance 57

Introduction $\quad 57$

Budget Monitoring 57

Analysing the Budget $\quad 58$

Phasing the Budget 59

Terminology 59

Taking Action $\quad 59$

Further Reading $\quad 60$

Chapter 8 Putting it all Together 61

Introduction 61

Organisational Structures $\quad 61$

The Challenge 63

How are Budgets Determined? 63

Cost Pressures 66

Devolved Management $\quad 67$ 


\section{Contents}

Appendix Table of discounting factors for calculating the net present value for capital projects $\quad 68$

Glossary of Terms 69

Further Advanced Reading $\quad \mathbf{8 0}$

Texts $\quad 80$

Research Papers 81

Magazine Articles and Journals $\quad 81$

Index $\quad 83$ 


\section{List of Figures and Tables}

\section{Figures}

1.1 Structure of the NHS and flow of funds 4

1.2 Stages leading to a contract 12

8.1 Organisational structure of a large acute hospital 62

Tables

1.1 Department of Health, central government's own expenditure

2.1 Example of a large capital expenditure proposal 19

2.2 Example of a small capital expenditure proposal 22

3.1 Costs and expected returns from three capital projects

3.2 Accounting rate of return 29

3.3 Spending and receipts profile 31

3.4 Net present value 33

3.5 Calculations of the discounted value (net present value) 34

5.1 Dental education: original budget 44

5.2 Dental education: budget report 45

8.1 Summary of income and expenditure for a large acute hospital $\quad 64$

8.2 Ward budget 65 


\section{Acknowledgements}

This book is the result of a long period of reflection about finance in the health service. The authors would like to thank everyone involved in that period of reflection, especially Richenda MiltonThompson and staff at Macmillan.

Thanks are also due to Professor Graham Kelly and Dr Roger Kendle for allowing us access to multi-disciplinary teams over a long period of years, and to Professor John Blake and Diane Roberts for their cheerful and unobtrusive encouragement. Finally, the greatest thanks to Angela Elsworth, Maria Wang, Penny Heaney and Sadiya Ali, without whose help this book would have remained a dream.

We hope that you, the reader, will write to us with improvements and suggestions for future editions, and we wish you every good wish in your professional career. 